\title{
Characterization of Archaeological European White Elm (Ulmus laevis P.) and Black Poplar (Populus nigra L.)
}

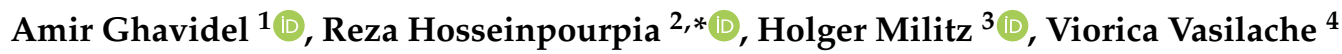 \\ and Ion Sandu ${ }^{5,6}$ (D) \\ 1 Faculty of Geography and Geology, Doctoral School of Geosciences, "Alexandru Ioan Cuza" \\ University of Iasi, 22 Carol I Blvd., 700506 Iasi, Romania; amir.ghavidelesfahlan@student.uaic.ro \\ 2 Department of Forestry and Wood Technology, Linnaeus University, Lückligs Plats 1, 35195 Växjö, Sweden \\ 3 Wood Biology and Wood Products, University of Göttingen, Buesgenweg 4, D-37077 Göttingen, Germany; \\ hmilitz@gwdg.de \\ 4 ARHEOINVEST Centrum, Institute of Interdisciplinary Research, "Alexandru Ioan Cuza” University of Iasi, \\ 11 Carol I Blvd., 700506 Iasi, Romania; viorica.vasilache@uaic.ro \\ 5 Academy of Romanian Scientists (AOSR), 54 Splaiul Independentei St., Sect. 5, 050094 Bucharest, Romania; \\ ion.sandu@uaic.ro \\ 6 Romanian Inventors Forum, 3 Sf.Petru Movila St, Bloc L11, Et, III, Ap. 3, 700089 Iasi, Romania \\ * Correspondence: reza.hosseinpourpia@lnu.se
}

Received: 17 November 2020; Accepted: 10 December 2020; Published: 14 December 2020

\begin{abstract}
The present study aims at characterization of freshly-cut and archaeological European white elm and poplar. The archaeological elm sample was buried at a depth of 8-10 m inside of soil with age approximation of $\sim 1800-2000$ years old, and the archaeological poplar sample was a part of a boat in a freshwater lake or river with age estimation of $\sim 1000-1200$ years. Alteration in the chemical structure of the elm and poplar samples due to the ageing process were confirmed by X-ray photoelectron spectroscopy (XPS). Both archaeological wood (AW) samples illustrated considerably lower cellulose crystallinity than the fresh samples as determined by X-ray diffraction. The sorption behavior of AW and fresh wood (FW) samples were evaluated by means of dynamic vapor sorption (DVS) analysis. Results exhibited a higher equilibrium moisture content (EMC) and sorption hysteresis values in archaeological elm and poplar as compared with the fresh samples. Higher hydrophilicity of the AW samples than the FW ones is attributed to their higher amorphous structure. The extensive degradation of AW samples were also confirmed by scanning electron microscopy (SEM) micrographs.
\end{abstract}

Keywords: X-ray photoelectron spectroscopy (XPS); X-ray diffraction (XRD); dynamic vapor sorption (DVS); archaeological wood; wood conservation and preservation

\section{Introduction}

Wood is an important renewable resource, and it has been the most important material in human's life since ancient times with various applications from constructions to furniture and from traditional household occupations to artefacts. The old wood constructions and artefacts represented worldwide are thus an important part of cultural heritage that must be acknowledged, understood, and conserved in accordance with the technical principles and code of ethics [1].

As defined previously, the term of archaeological wood (AW) refers to a dead wood used by an extinct human culture, that may or may not has been modified for or by use, and that was discarded into a specific natural environment [2-4]. Wood, as an organic material, is susceptible to abiotic 
and biotic deterioration. Abiotic factors such as weather, fire, and aggressive chemicals degrade the wood structure, and particular changes occur on the surface [5]. Changes in the ambient humidity cause swelling and shrinkage in wood cells, resulting in changes in the cell dimensions over time, as well as slow hydrolysis of polysaccharide compounds, oxidation of lignin, and leaching of degraded products and extractives from the cell walls [2]. While biotic factors are an essential part of the carbon cycle. A number of different microorganisms such as insects, calms, nematodes, fungi, and bacteria can damage the wood structure. Many fungi can degrade the cellulose fibers, but only a limited number of so-called cellulolytic fungi can break down the highly crystalline part of the cellulose. Bacteria, in addition to wood rot spores, can also weaken wood in such a way that substantial strength losses can be encountered. Three types of wood degrading bacteria are known in the literature based on their specific micro-morphological features: tunneling bacteria, erosion bacteria, and cavitation bacteria [6]. Finding has shown that tunneling bacteria (TB) can be present in conditions similar to soft rot, while erosion bacteria (EB) are capable of rotting wood in environments with very low oxygen supply [7]. When wood is submerged underwater or buried in soil, due to the absence of oxygen, the process of co-called wood fossilization is initiated [8]. The rate of wood fossilization and the degradation level of wood polymers increase by the time of deposition [9]. The chemical composition of AW or subfossil wood and the resulting physical and mechanical properties during long-term contact with the soil imply lower cellulose and higher lignin content in fossil wood as compared with FW [8]. Changes in the chemical structure of AW due to environmental elements or application sites have been studied previously [10]. Popescu et al. [11] reported that the chemical structure of archaeological lime obviously changed during the first ageing period, which is normally around 150 years. Lime wood sample showed the highest percentage of carbon atoms and the lowest content of oxygen atoms on the surface. The extractive content of archaeological lime was also considerably reduced because of oxidation and mild hydrolysis. Lucejko et al. [12] studied the degradation processes induced by the burial environment of archaeological oak. The authors quoted that only small chemical transformation of the polysaccharide component, mainly involving hemicelluloses, occurred during the burial time, which could be due to the heterogeneity and inhomogeneity of the natural composition of oak wood. Kacík et al. [13] evaluated the changes in the cellulose, hemicelluloses, lignin, and extractives contents in 108 to 390 years old fir. They observed higher extractive content and lower amount of hemicelluloses in naturally aged fir wood than the fresh wood. Cellulose, lignin, and hemicellulose are known to degrade over time, and the amounts of these elements decrease in the wood, whereas extractives can remain unchanged. It is possible for the wood to absorb chemicals such as limestone, through storing it in the lumens. Still, the initial wood extractives would not increase and are more likely to decrease depending on the burial site [8]. Evaluation of archaeological elm (Ulmus sp.) wood with about 350 years old from Chenghuang Temple, China, showed obvious decreases in carbohydrates and lignin contents, deterioration in microstructures, and alteration in micromechanical properties at the surface layer of wood as a result of ageing process or weathering [14]. Bader and co-workers [15] analyzed the chemical compositions and microstructure-mechanics of load-bearing archaeological oak of the Oseberg Viking ship. They reported although hemicelluloses and amorphous cellulose were clearly degraded in AW, the cell wall stiffness was increased, as determined by nanoindentation. It is known that the combination of oxygen and solar radiation rapidly induces oxidation of lignin and hemicelluloses and also depolymerizes the amorphous part of cellulose [16]. The degraded products are water-soluble and will be easily removed from the wood surface by rain, and as a result discoloration of wood surface occurs $[8,17,18]$. These deterioration mechanisms depend on the conditions that wood is stored and used. However, even under most favorable conditions, a long-term ageing process can degrade the wood polymers [10].

The hygroscopic structure of wood is attributed to the presence of different hydrophilic polymers in the cell wall, that contain hydroxyl groups. The most hydrophilic polymers in the wood are hemicelluloses followed by amorphous cellulose and lignin [19-21]. Changes in the chemistry of wood cell wall due to the ageing process, i.e., in AW, directly affect its performances. Controlling the 
hygroscopicity of AW is a fundamental concern of the conservator [22]. Popescu and Hill [23] analyzed the water vapor sorption of naturally aged Tilia cordata Mill. and reported different sorption behavior in the historical wood samples as compared to fresh ones, suggesting a potential annealing reaction associated with plasticization of the cell wall matrix at high moisture content. Sonderegger and colleagues [24] claimed that natural ageing affected the physical and mechanical properties of spruce, fir, and oak wood, but the effect on sorption and swelling behavior of wood was negligible. No differences or marginal shifts on equilibrium moisture content (EMC) of various AW species as compared with FW were reported by Kranitz et al. [25].

Characteristics of AW differ by their place of application (buried, submerged, exposed, etc.), and studying these types of materials bring additional information on the long-term performances of wood products. This knowledge will also help us to provide a proper conservation plan for wooden objects of cultural importance. Therefore, the main aim of the present study was to characterize the archaeological European white elm (Ulmus laevis P.) and black poplar (Populus nigra L.) wood samples and to compare them with the freshly cut wood samples. The chemical structure and crystallinity of the samples were respectively analyzed by means of XPS spectroscopy and X-ray diffraction methods. Dynamic vapor sorption (DVS) analysis was also conducted to evaluate the sorption behavior of AW and FW samples.

\section{Materials and Methods}

\subsection{Raw Materials and Samples Preparations}

Freshly cut elm (Ulmus laevis P.) and poplar (Populus nigra L.) wood samples were received from a sawmill. This consisted of $45 \times 90 \times 4000 \mathrm{~mm}(\mathrm{~L} \times \mathrm{T} \times \mathrm{R})$ boards from Romanian growth area Suceava. The defect-free samples (no knots, cracks, reaction wood) with annual growth rings slope of $<5^{\circ}$ were taken from heartwood. The moisture contents of FW elm and poplar were $7.66 \%$ and $7.79 \%$, respectively. The respective density of FW elm and poplar were $0.55 \mathrm{~g} / \mathrm{cm}^{3}$ and $0.42 \mathrm{~g} / \mathrm{cm}^{3}$. The elm AW sample was collected from sand mines, buried at a depth of $8-10 \mathrm{~m}$ in the alluvial soil from the former Somes riverbed, in the region of Satu Mare-Romania and county of Vetis. Age of the elm AW is estimated to be around 1800 to 2000 years, and its form of application on that place is unclear. The poplar AW sample was received from the historical museum of Iasi-Romania. This sample was part of a boat in a freshwater lake or river. The age of this sample is approximately 1000 to 1200 years. The age of both AW samples were determined by stratigraphic evaluation method based on the landmarks of ceramics and the numismatic pieces found in the layer next to the wooden artefact, also according to the archived documents [3]. It should be noted that because of the specks of dirt and other impurities, such as soil, the external surfaces of both AW samples were removed by $20-30 \mathrm{~mm}$, prior to analysis.

\subsection{X-Ray Photoelectron Spectroscopy (XPS)}

XPS analysis was carried out on the samples measuring $1 \times 5 \times 5 \mathrm{~mm}^{3}(\mathrm{~L} \times \mathrm{T} \times \mathrm{R})$ by the PHI VersaProbe II spectrometer (Ulvacphi, Inc., Osaka, Japan) using a monochromatic Al-K $\alpha$ source with photonic energy of $1486.6 \mathrm{eV}$ and a base pressure of $2 \mu \mathrm{Pa}$, as described previously [10]. All samples were analyzed at room temperature without prior sample surface purification. Two measurements were performed for each wood type, and the average value was calculated.

\subsection{X-Ray Diffraction Analysis (XRD)}

Degree of wood crystallinity was measured with X-ray diffraction analysis using a Philips X'Pert MPD PW 3040 diffractometer (Netherlands) equipped with a PW 3050/10 goniometer, divergence slit $0.5^{\circ}$, anti-scatter slit $0.5^{\circ}$, receiving slit $0.6 \mathrm{~mm}$, secondary graphite monochromator, mask $15 \mathrm{~mm}$, $40 \mathrm{kV}$ activity, and $30 \mathrm{~mA}$ with $\mathrm{Cu} \mathrm{K} \alpha$ radiation. The analysis was performed according to our previous study [10] following the scanning range of $5-50^{\circ} 2 \theta$ with a phase width of $0.02^{\circ} 2 \theta$ in a continuous 
mode. Sample spinning was at $1 \mathrm{rps}$, and the counting time was $4 \mathrm{~s}$ per move. Wood samples were milled in a planetary ball mill (P7 premium first, Fritsch) and prepared in $16 \mathrm{~mm}$ sample holders using backloading.

\subsection{DVS Analysis}

Dynamic vapor sorption behavior of wood samples were analyzed using DVS apparatus (DVS advantage, Surface Measurement Systems, London, UK), as described previously [6,10,26-28]. Wood samples were milled and passed through the 2-mm mesh. Approximately $20 \mathrm{mg}$ of the milled samples were placed on a DVS sample holder. Sorption isotherms were recorded at a constant temperature of $25^{\circ} \mathrm{C}$. The relative humidity (RH) was increased in the following sequence: $0 \%, 5 \%$, $15 \%, 25 \%, 35 \%, 45 \%, 55 \%, 65 \%, 75 \%, 85 \%$, and $95 \% \mathrm{RH}$, and followed in reverse order to $0 \% \mathrm{RH}$. The RH was maintained until the mass change of the specimen per minute was $<0.001 \% \mathrm{~min}^{-1}$ over a period of $10 \mathrm{~min}$ and the equilibrium mass of the specimen recorded. At each $\mathrm{RH}$ the weight at equilibrium condition was recorded by micro-balance and then equilibrium moisture content (EMC) was assessed, accordingly.

\subsection{Scanning Electron Microscope (SEM)}

The microstructure of AW and FW elm and poplar samples were evaluated by TESCAN MIRA3 FEG-SEM (Czechia) operating at a $70 \mathrm{~Pa}$ vacuum and a $15 \mathrm{kV}$ accelerating voltage. The samples measuring $10 \times 10 \times 10 \mathrm{~mm}^{3}$ were cut with a razor blade before imaging, according to our previous study [6].

\section{Results and Discussion}

\subsection{XPS}

Figure 1 shows the C1s energy level spectra of AW and FW wood samples analyzed by XPS spectroscopy. The conforming surface composition within the C1s energy level is illustrated in Table 1 . The C1s signal encompasses four sub-peaks, e.g., C1, C2, C3, and C4 [29]. The C1 is related to the carbon atoms that are bonded with either carbon or hydrogen. The $\mathrm{C} 2$ signal assigns to the carbon atom single is bonded with an oxygen atom. The $\mathrm{C} 2$ signal in wood sample is related to the carbohydrates, mainly cellulose, and hemicelluloses [29,30]. The carbonyl groups are indicated by $\mathrm{C} 3$ stretching band, while carboxyl groups are shown by $\mathrm{C} 4$ peak.

The $\mathrm{C} 1$ sub-peak area significantly increased in both AW samples. The C1 signal is mainly attributed to extractives and lignin of wood [11]. This fact shows a lower concentration of oxygenated $\mathrm{C}$ atoms. Referring to the FTIR results in our previous study [6], this increase indicates that the amount of lignin was increased after the ageing process, which might be related to the reduction in carbohydrate content. The $\mathrm{C} 2$ sub-peak in elm sample decreased after the ageing process, while it is slightly increased in archaeological poplar. The absorption in C3 peaks in both AW (elm and poplar) samples are decreased after the ageing process. This indicates that the quantity of carboxyl groups are decreased, which might be due to the oxidation and hydrolysis process in contact with soil, change in humidity and ultra-violet (UV) light degradation [31]. The abiotic degradation of wood by weathering elements such as UV light, however, occurs at maximum 1-2 mm depth [5], while the samples in this study were obtained from a deeper part of the surface. Therefore, other degradation mechanisms than weathering factors must be involved. 

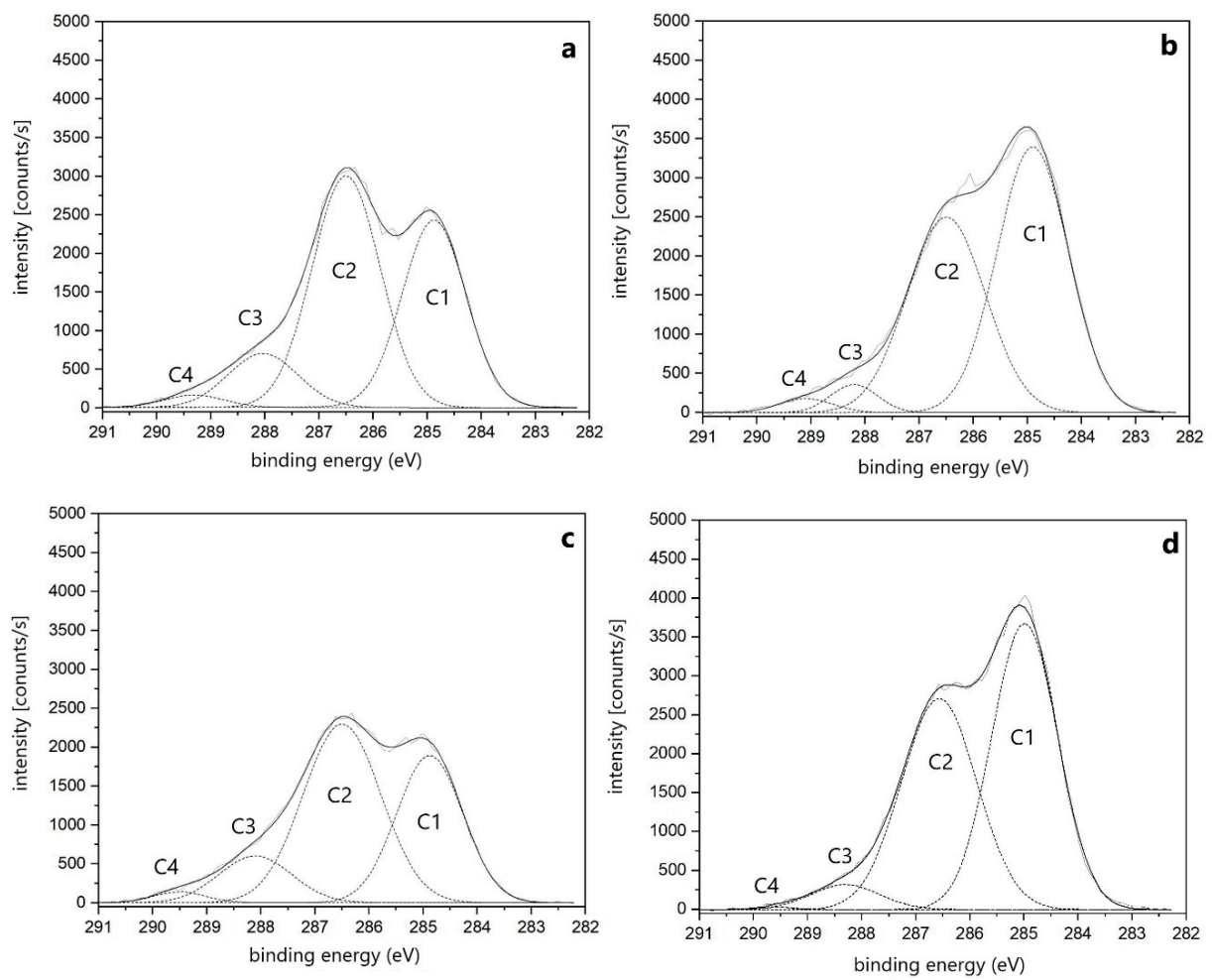

Figure 1. High-resolution spectra of the $\mathrm{C} 1$ s energy level of (a) fresh elm, (b) archaeological elm, (c) fresh poplar, and (d) archaeological poplar.

Table 1. Relative surface composition for fresh and archaeological elm and poplar.

\begin{tabular}{ccccccc}
\hline Wood Samples & $\begin{array}{c}\text { C1 } \\
\text { (atm.\%) }\end{array}$ & $\begin{array}{c}\text { C2 } \\
\text { (atm.\%) }\end{array}$ & $\begin{array}{c}\text { C3 } \\
\text { (atm.\%) }\end{array}$ & $\begin{array}{c}\text { C4 } \\
\text { (atm.\%) }\end{array}$ & $\begin{array}{c}\text { Atomic } \\
\text { Ratio O/C }\end{array}$ & Cox/Cunox \\
\hline Fresh elm & $36.2( \pm 8.0)$ & $51.1( \pm 4.4)$ & $10.3( \pm 2.5)$ & $2.3( \pm 1.4)$ & 0.42 & 1.75 \\
Archaeological elm & $54.1( \pm 2.9)$ & $38.9( \pm 3.8)$ & $5.2( \pm 0.5)$ & $1.8( \pm 0.4)$ & 0.32 & 0.84 \\
Fresh poplar & $43.5( \pm 7.0)$ & $42.6( \pm 1.3)$ & $11.4( \pm 6.6)$ & $2.5( \pm 1.0)$ & 0.42 & 1.29 \\
Archaeological poplar & $48.8( \pm 2.7)$ & $42.0( \pm 4.9)$ & $7.2( \pm 5.1)$ & $2.0( \pm 2.3)$ & 0.28 & 1.04 \\
\hline
\end{tabular}

The atomic ratio and Cox/Cunox in both AW samples were lower than the FW ones. These differences can be attributed to the oxidation and hydrolysis reactions of carbon-containing compounds in the deeper parts of AWs and migration of the degraded products to the surface during the ageing process $[11,30,32]$.

The O1 energy level spectra of AW and FW samples are shown in Figure 2. The O1 energy level includes two sub-peaks, namely $\mathrm{O} 1$ and $\mathrm{O} 2$. The $\mathrm{O} 1$ sub-peak related to an oxygen atom that is linked with a double bond to a carbon atom, and the $\mathrm{O} 2$ sub-peak, with higher binding energy, reflects an oxygen atom linked to a carbon atom by a single bond. An apparent reduction observed in $\mathrm{O} 2$ sub-peak of archaeological elm while there were no significant changes observed in the archaeological poplar. This variation is in accordance with the FTIR analysis in our previous study [6], which could be related to the $\mathrm{C}=\mathrm{O}$ bond in hemicellulose.

The XPS results demonstrate the depolymerization, oxidation, and hydrolysis reactions on the surface of AW samples [11]. These findings are compatible with the FTIR spectroscopic data obtained in our previous study [6], which show that hemicelluloses and amorphous part of cellulose polymers are degraded over the exposure time. Although the crystalline part of cellulose is more stable to degradation, due to the sever ageing process and soil contact, most crystalline regions were degraded. The lignin is a stability polymer and it was no rapid deterioration found due to ageing process [11]. Fors [33] reported that the ratio of lignin to cellulose increases as the wood is degraded. Wood-decay fungi require oxygen to gain ATP for cellular metabolism and hyphal growth, 
and also for active expression and secretion of an array of enzymes and metabolites to decompose the wood polymers [34-36]. The AW samples that analyzed in this study collected from the places with a low oxygen content, e.g., under soil or fresh water, and thus it is unlikely that the wood-decay fungi degraded the structure of AW samples. It is well-known that bacteria are more tolerant to conditions considered extreme for most wood-decay fungi. Erosion bacterial is also widely accepted as a destruction agent in AW under conditions with limited oxygen availability [37]. Therefore, it is expected that the degradation in cell wall polymers of archaeological elm and poplar is caused by erosion bacteria. In addition, selective degradation by fungi and moisture changes may occur in archaeological poplar as it was located in aquatic media and then left under humid conditions for some periods. Placing the archaeological poplar in the museum may also cause photo-degradation with visible light $[38,39]$.
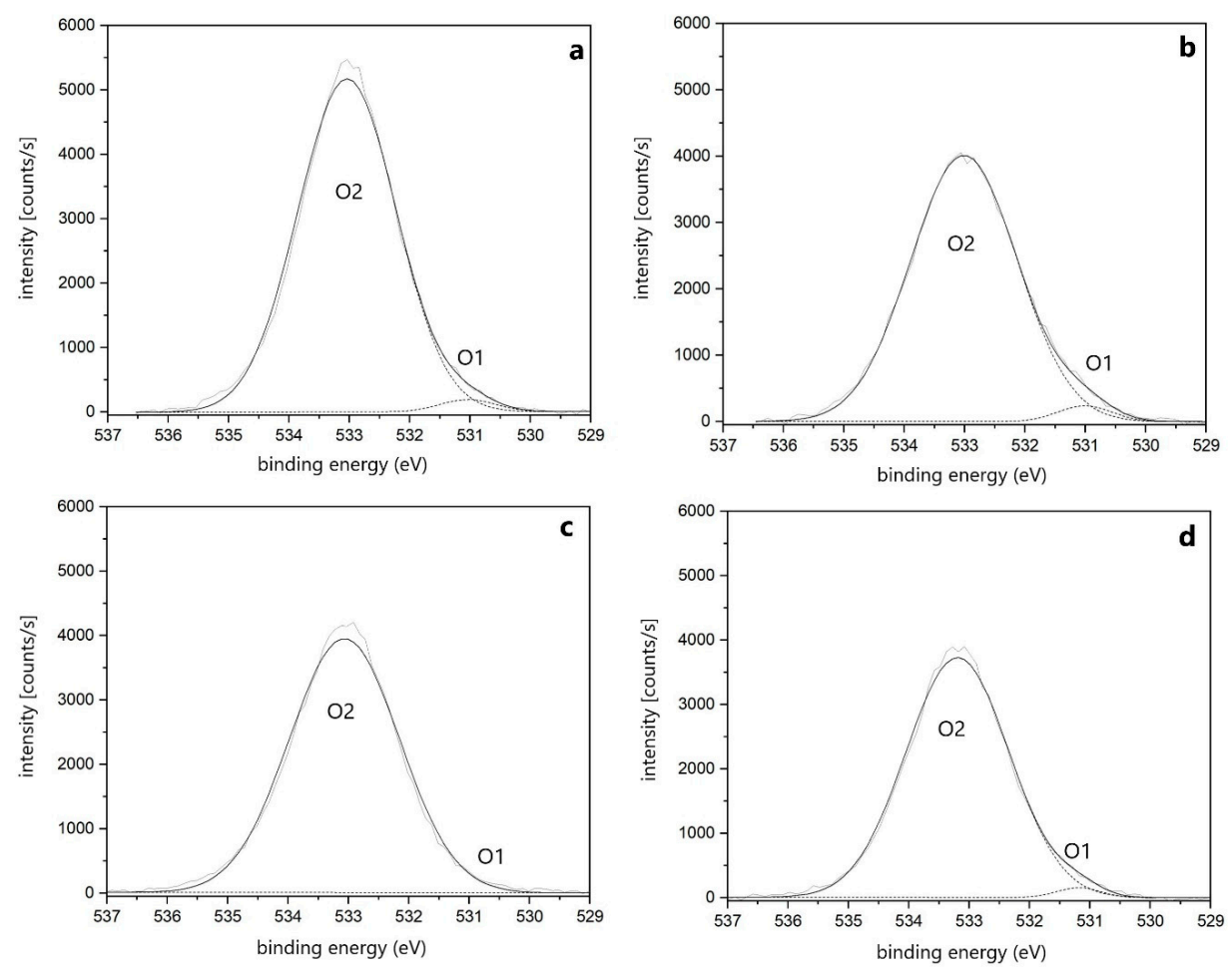

Figure 2. High-resolution spectra of the O1s energy level of (a) fresh elm, (b) archaeological elm, (c) fresh poplar, and (d) archaeological poplar.

\section{2. $X R D$}

The X-ray diffractograms of the AW and FW samples are illustrated in Figure 3a,b. In order to measure the intensities of diffraction bands, to verify the crystalline and amorphous areas, and to determine the crystallite size, the Gaussian profiles were used to deconvolute the diffractograms, as explained previously [10]. The peak intensity and peak expansion are differed in wood species due to the ageing process. Firm peaks observed in the range between $20.50^{\circ}$ and $22.50^{\circ} 2 \theta$ in $\mathrm{FW}$ of elm and poplar, while the AW displayed much broader and weaker diffraction peaks. The reflection from $16.14^{\circ}$ to $17.94^{\circ} 2 \theta$ is assigned to the amorphous part of lignocellulosic materials [40]. The results indicate a much lower degree of crystallinity and greater amorphous regions in the AW samples. In comparison with archaeological poplar, the reflection peaks in archaeological elm is much weaker, which can be related to its age, i.e., approximately 600-800 years older than poplar, and also stronger degree of degradation.

The maximum (I200) and minimum (Iam) intensities of the crystalline cellulose, the crystalline index (CrI) and the crystallite size $(L)$ are shown in Table 2 . The $L$ values were smaller for both AW 
samples. This decreasing together with the decreasing in $\mathrm{CrI}$ indicate the increase of the amorphous domains [41]. The CrI in both AW samples were lower than the FW ones. This might be attributed to the removing of extractives and also to the effects of repetitive ageing processes during absorption and desorption of moisture or liquid water [40], due to the fact that both AW samples were collected from moist conditions. Biological degradation of AW samples can be an additional reason since both elm and poplar specimen were collected from the places with the possible destruction by erosion bacteria [6] and selective fungi degradation, in the case of archaeological poplar.
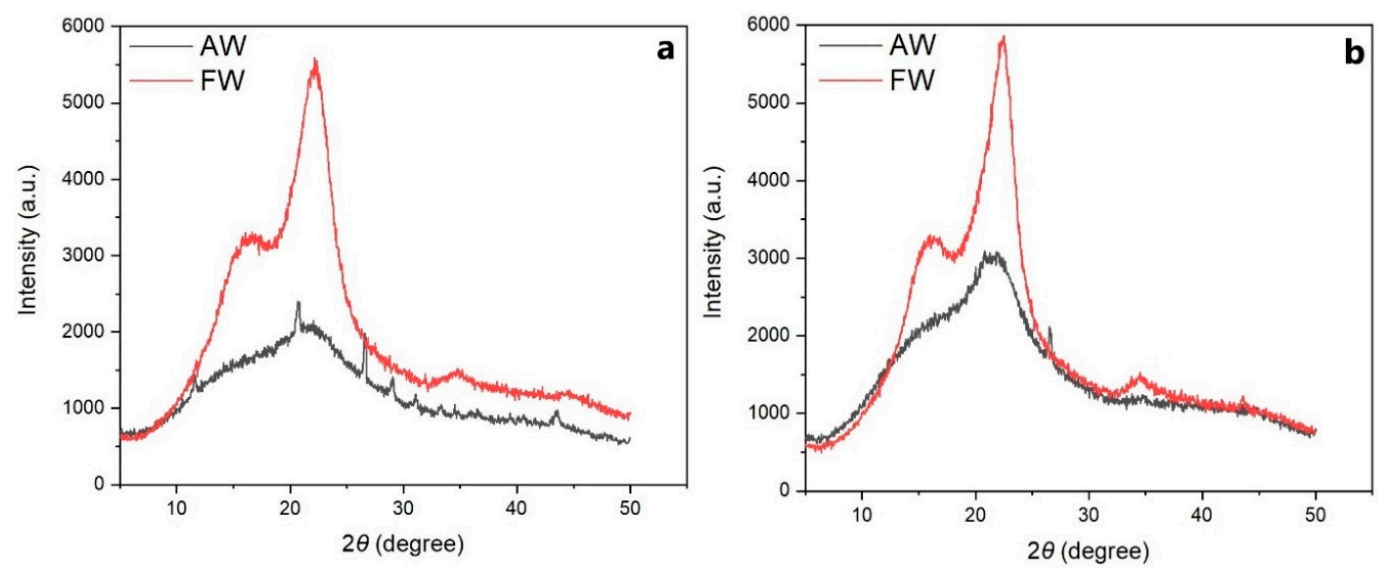

Figure 3. X-ray diffractograms from archaeological wood (AW) and fresh wood (FW) of elm (a) and poplar (b).

Table 2. Band positions of crystalline and amorphous cellulose and the calculated parameters for the wood samples.

\begin{tabular}{ccccc}
\hline Wood Samples & I200 & Iam & CrI (\%) & L (200) (nm) \\
\hline Fresh-elm & 20.14 & 17.26 & 42.26 & 8.23 \\
Archaeological-elm & 22.06 & 16.82 & 26.13 & 5.69 \\
Fresh-poplar & 22.5 & 18.14 & 49.91 & 8.18 \\
Archaeological-poplar & 20.78 & 17.62 & 29.11 & 6.85 \\
\hline
\end{tabular}

\subsection{Sorption Isotherms}

The adsorption and desorption isotherms of elm and poplar AW and FW are shown in Figure 4a,b. The isotherm curves of fresh and archaeological elm and poplar samples exhibited a type II sigmoid character of cellulose-containing materials. The ageing phenomena altered the sorption behavior of elm and poplar samples through whole adsorption and desorption runs. Both AW samples showed higher equilibrium moisture content (EMC) values during absorption and desorption processes as compared with the fresh samples throughout the entire hygroscopic ranges. The high absorption and desorption values in AW samples could be explained by the alteration on their chemical structure [42-44], and also disordering their crystalline regions [45]. We found previously that the decomposition in polysaccharides of archaeological elm was more pronounced. A similar chemical change was observed in the archaeological poplar (unpublished results). This together with the XRD results, in Figure 3, confirms that the amorphous parts of AW samples were considerably increased, which will lead to the higher flexibility of cell wall polymer to accommodate water molecules during the sorption processes. A similar trend observed previously in delignified wood micro-veneers [44]. Hydrophilic structure of Scots pine (Pinus sylvestris) after degradation by brown-rot fungi showed Chirkova et al. [42]. Analyzing the sorption properties of 103 years old Scots pine showed that because of the degradation of hemicellulose and decreasing in the crystallinity index, the EMC in AW sample was higher than the FW. Most recently, García-Iruela and co-workers [45] quoted that the higher moisture adsorption of AW (Pinus sylvestris L. with 400 years old) than the FW is related to the greater availability of active 
hydroxyl groups. Biological degradation of the samples due to ageing condition may also enhance the hydrophilic structure of wood polymers, and thus increase the number of active sorption sites.
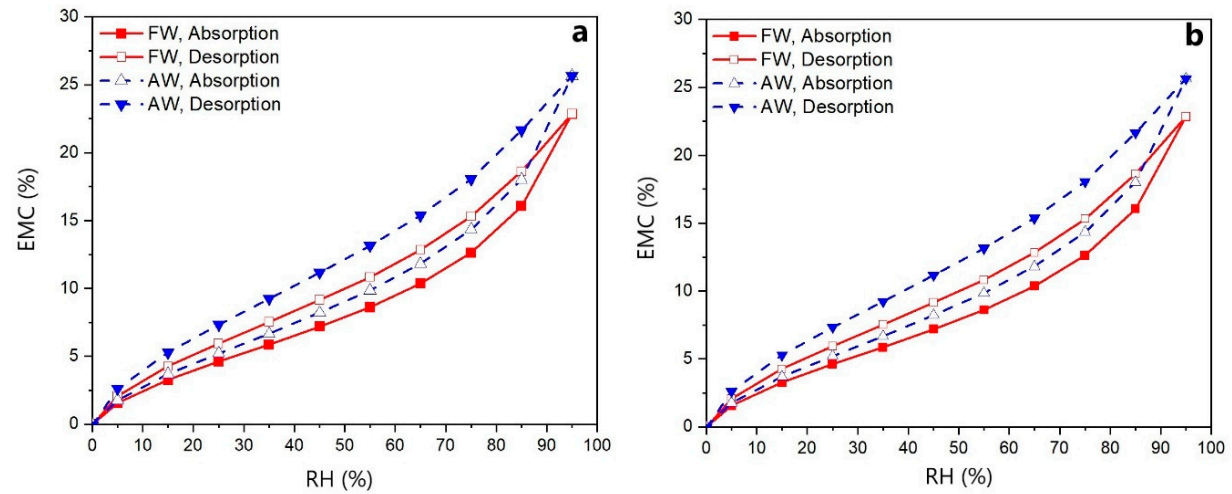

Figure 4. Adsorption and desorption isotherms of archaeological and fresh elm (a) and poplar (b) at a given relative humidity $(\mathrm{RH})$ level.

The sorption hysteresis of archaeological and fresh elm and poplar are shown in Figure 5a,b. The AW samples illustrated greater differences between the EMC values during desorption and adsorption runs, which resulted in a larger hysteresis loop area. It is evident that the sorption hysteresis is slightly higher in both archaeological and fresh elm as compared with the ones in poplar. The highest hysteresis value was obtained in the archaeological elm samples. The hysteresis values in fresh and archaeological elm were $3.03 \%$ and $3.86 \%$, respectively, whereas poplar samples show the respective values of $2.7 \%$ and $3.68 \%$. As indicated in the XRD results, the crystalline structure of wood samples were considerably decreased because of ageing conditions. Therefore, the sorption hysteresis of these samples could be related to the behavior of the highly amorphous matrices, mainly during the desorption run. With regard to the adsorption process, the water molecules are adsorbed by the amorphous structure of wood samples resulting in swollen cell wall matrix. Because of the extensive degradation of AW polymers, the ability of the degraded polymers to rearrange of cell wall matrices during desorption process is inhibited, and thus greater time lag occurs for matrix relation, as postulated by Lu and Pignatello [46]. The different sorption behavior of archaeological elm and poplar might be attributed to the differences in their condition of exposure and degradation mechanisms [47]. A greater hygroscopic behavior and sorption hysteresis of 205 years old Pinus sylvestris L. as compared with the FW was reported to be mainly due to the decreases in the crystalline structure of AW [48]. Similar results were reported by García-Iruela and colleagues [45], who explained that the selective degradation mechanisms by fungi and bacteria and also exposure to various humid atmospheres are the main reasons to enhance the amorphous regions, and thus provide more hydrophilic structure in AW than the fresh wood.
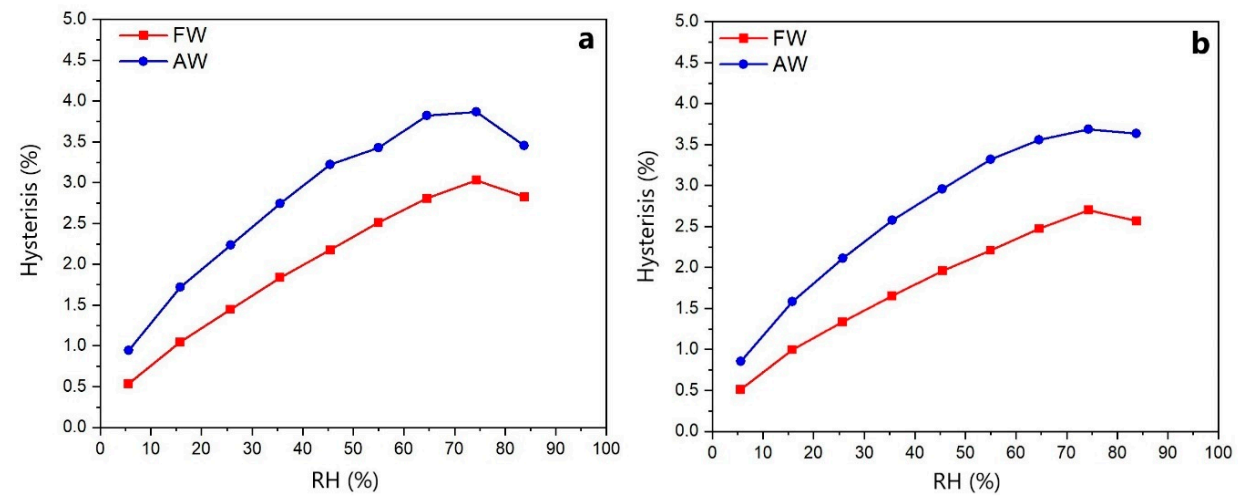

Figure 5. Sorption hysteresis of archaeological and fresh elm (a) and polar (b) at a given RH level. 


\subsection{Scanning Electron Microscope (SEM)}

SEM micrographs of archaeological and fresh elm and poplar samples are presented in Figures $6 \mathrm{a}-\mathrm{d}$ and $7 \mathrm{a}-\mathrm{d}$. As can be seen in these images, the structures of both wood species were severely degraded because of the ageing conditions. Considerable degradation was observed in the wood rays, particularly in poplar. Those cells are part of the nutrient reserves of the trees and contain a higher quantity of sugars compared to other cell types, such as fibers and vessels [49]. The deteriorated rays indicate that the sugars were the first ones affected by the degradation factors. The destruction in archaeological elm sample can be attributed to the many years of exposure underground, and obvious degradation of cell wall polymers, as reported in our previous study [6]. Although poplar is very low durable species [50], exposure of archaeological poplar to water and also humid conditions may enhance the degradation rates in this sample. Furthermore, local environmental degradation factors such as bacteria, fungi, and $\mathrm{pH}$ of the soil (in elm sample) and of the water (in poplar sample) could be considered as additional reasons [8].
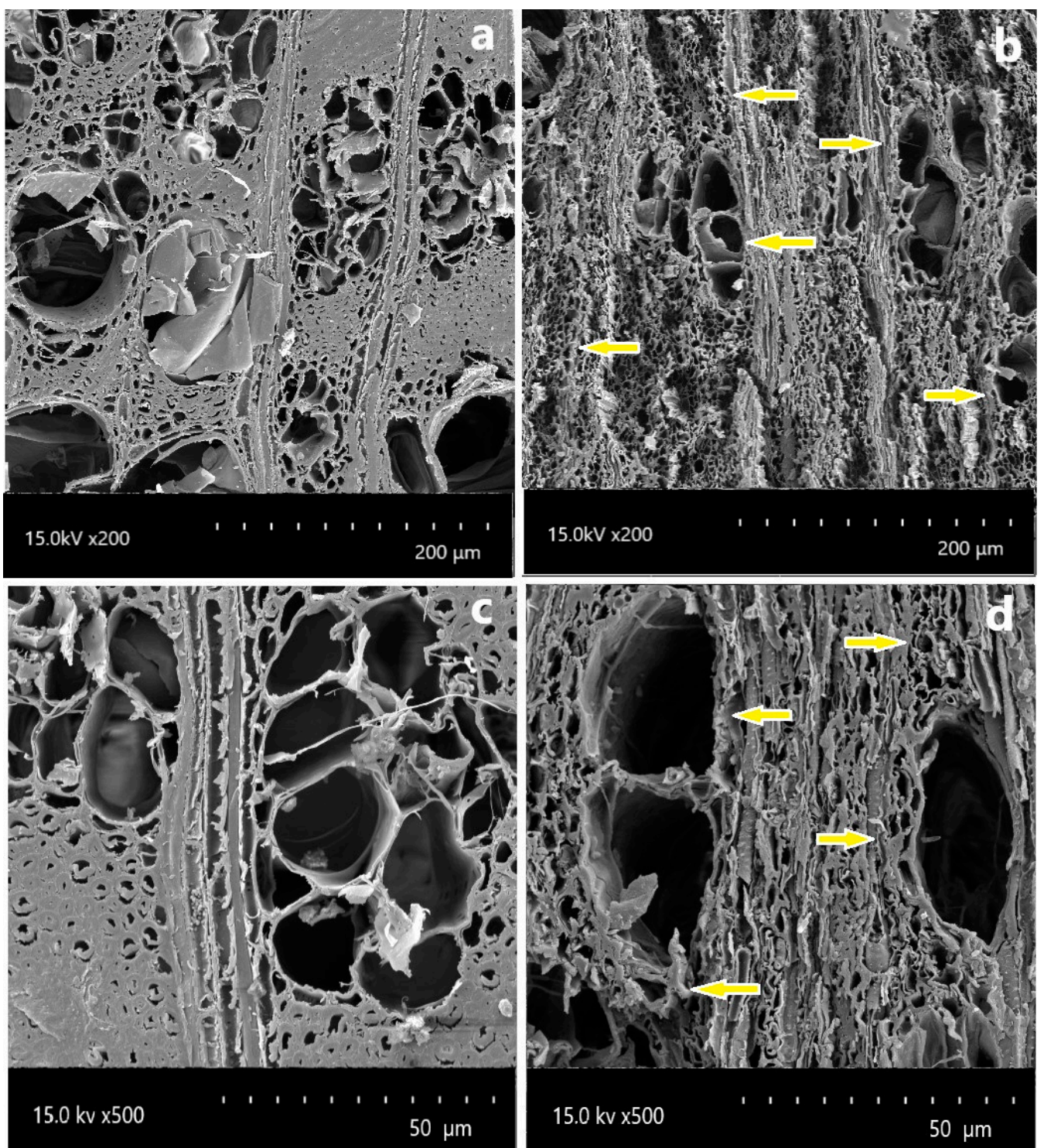

Figure 6. Scanning electron microscopy (SEM) micrographs of fresh and archaeological elm at $200 \mu \mathrm{m}$ $(\mathbf{a}, \mathbf{b})$, and $50 \mu \mathrm{m}(\mathbf{c}, \mathbf{d})$ magnification. Arrows indicate the damaged parts of AW. 

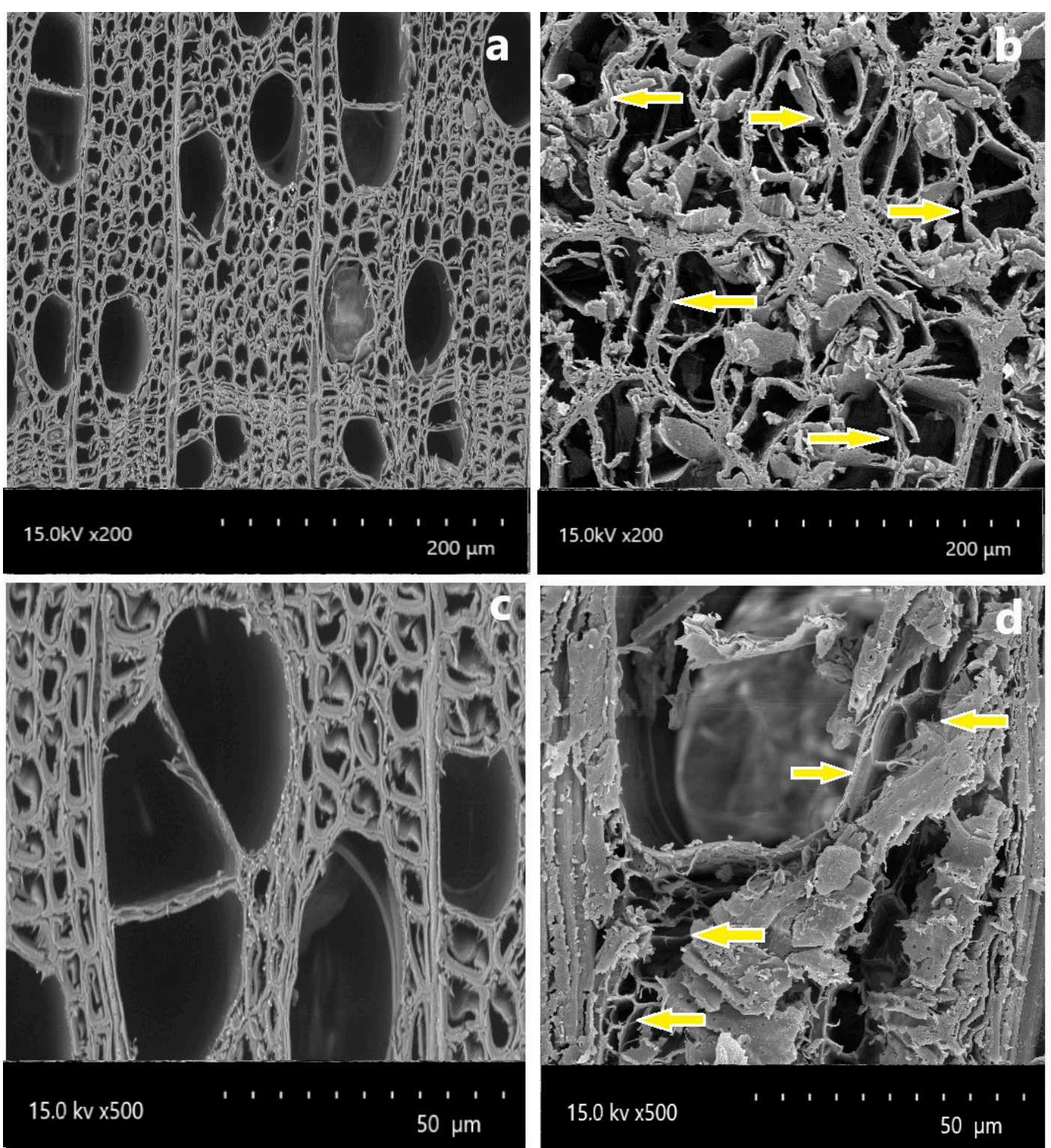

Figure 7. Scanning electron microscopy (SEM) micrographs of fresh and archaeological poplar at $200 \mu \mathrm{m}(\mathbf{a}, \mathbf{b})$, and $50 \mu \mathrm{m}(\mathbf{c}, \mathbf{d})$ magnification. Arrows indicate the damaged parts of AW.

\section{Conclusions}

The fresh and archaeological European white elm (Ulmus laevis P.) and black poplar (Populus nigra L.) wood samples were studied by means of their chemical and crystalline structures, sorption behavior, and microstructure characters. Depolymerization, oxidation, and hydrolysis reactions occurred in the archaeological samples, as indicated by lower ratios of Cox/Cunox and O/C than fresh samples. The crystalline structure of both elm and poplar samples were also considerably decreased because of the ageing conditions. Accordingly, higher EMC values during adsorption and desorption processes were obtained in the archaeological samples as compared to the fresh ones. The greater sorption hysteresis in archaeological elm and poplar samples than the fresh specimens are expected to be due to the inability of the cell wall to rearrange during the desorption run, because of the severe degradation process. Slight differences were observed in the microstructure of archaeological elm and poplar samples, which are mainly related to their condition of exposure and degradation mechanisms.

Proper conservation of wooden artefacts is dependent upon a knowledge of wood species, microstructure, cell wall chemistry, and its hydrophilic character. This information is critical for 
conservators to use a suitable conservation method and chemicals. For instance, polyethylene glycol (PEG) is a conservation agent and it is expected to stabilize in wood by chemical reaction with wood polymers, and thus changes in the chemical structure of wood affect its stabilization. Therefore, our study is anticipated to provide a better understanding on the chemical, physical, and microstructural characters of AW samples exposed at various degradation conditions.

Author Contributions: Conceptualization, A.G., R.H.; methodology: A.G., R.H., H.M.; V.V.; validation: A.G., I.S.; investigation: A.G.; resources: A.G., R.H., H.M., I.S.; writing-original draft preparation: A.G., R.H.; writing-review and editing: all authors; All authors have read and agreed to the published version of the manuscript.

Funding: This research received no external funding.

Acknowledgments: We thank the Department of Wood Biology and Wood Products and the Geoscience Centre, Georg-August-University Göttingen, and the Faculty of Natural Sciences and Technology, University of Applied Sciences and Arts HAWK, Göttingen, for their collaboration and support to perform this research.

Conflicts of Interest: The authors declare no conflict of interest.

\section{References}

1. Unger, A.; Schniewind, A.P.; Unger, W. Conservation of Wood Artifacts; Springer: Berlin/Heidelberg, Germany, 2001.

2. Walsh-Korb, Z.; Avérous, L. Recent developments in the conservation of materials properties of historical wood. Prog. Mater. Sci. 2019, 102, 167-221. [CrossRef]

3. Sandu, I.C.A.; Brebu, M.; Luca, C.; Sandu, I.; Vasile, C. Thermogravimetric study on the ageing of lime wood supports of old paintings. Polym. Degrad. Stab. 2003, 80, 83-91. [CrossRef]

4. Florian, M.L.E. Scope and history of archaeological wood. In Archaeological Wood: Properties, Chemistry, and Preservation; Rowell, R.M., Barbour, R.J., Eds.; American Chemical Society: Washington, DC, USA, 1990; pp. 3-32.

5. Reinprecht, L. Wood Deterioration, Protection and Maintenance; John Wiley and Sons: West Sussex, UK, 2016.

6. Ghavidel, A.; Gelbrich, J.; Kuqo, A.; Vasilache, V.; Sandu, I. Investigation of archaeological European white elm (Ulmus laevis) for identifying and characterizing the kind of biological degradation. Heritage 2020, 3, 1083-1093. [CrossRef]

7. Björdal, C.G.; Nilsson, T.; Daniel, G.F. Microbial decay of waterlogged archaeological wood found in Sweden-Applicable to archaeology and conservation. Int. Biodeterior. Biodegrad. 1999, 43, 63-71. [CrossRef]

8. Ghavidel, A.; Hofmann, T.; Bak, M.; Sandu, I.; Vasilache, V. Comparative archaeometric characterization of recent and historical oak (Quercus spp.) Wood. Wood Sci. Technol. 2020, 54, 1121-1137. [CrossRef]

9. Christiernin, M.; Notley, S.M.; Zhang, L.; Nilsson, T.; Henriksson, G. Comparison between 10,000-year old and contemporary spruce lignin. Wood Sci. Technol. 2009, 43, 23-41. [CrossRef]

10. Ghavidel, A.; Scheglov, A.; Karius, V.; Mai, C.; Tarmian, A.; Vioel, W.; Vasilache, V.; Sandu, I. In-depth studies on the modifying effects of natural ageing on the chemical structure of European spruce (Picea abies) and silver fir (Abies alba) woods. J. Wood Sci. 2020, 66, 77. [CrossRef]

11. Popescu, C.M.; Tibirna, C.M.; Vasile, C. XPS characterization of naturally aged wood. Appl. Surf. Sci. 2009, 256, 1355-1360. [CrossRef]

12. Lucejko, J.J.; Tamburini, D.; Zborowska, M.; Babiński, L.; Modugno, F.; Colombini, M.P. Oak wood degradation processes induced by the burial environment in the archaeological site of Biskupin (Poland). Herit. Sci. 2020, 8, 1-12. [CrossRef]

13. Kacík, F.; Šmíra, P.; Ka`cíková, D.; Reinprecht, L.; Nasswettrová, A. Chemical changes in fir wood from old buildings due to ageing. Cellul. Chem. Technol. 2014, 48, 79-88.

14. Han, L.; Wang, K.; Wang, W.; Guo, J.; Zhou, H. Nanomechanical and topochemical changes in elm wood from ancient timber constructions in relation to natural aging. Materials 2019, 12, 786. [CrossRef] [PubMed]

15. Bader, T.K.; de Borst, K.; Fackler, K.; Ters, T.; Braovac, S. A nano to macroscale study on structure-mechanics relationships of archaeological oak. J. Cult. Herit. 2013, 14, 377-388. [CrossRef] 
16. Polle, A.; Otter, T.; Sandermann, H. Biochemistry and physiology of lignin synthesis. In Plant Physiology of Trees; Rennenberg, H., Eschrich, W., Ziegler, H., Eds.; Backhuys Publishers: Leiden, The Netherlands, 1997; pp. $455-475$.

17. Hedges, J.I. The chemistry of archaeological wood. In Archaeological Wood: Properties, Chemistry, and Preservation; Rowell, R.M., Barbour, R.J., Eds.; Advances in Chemistry Series 225; American Chemical Society: Washington, DC, USA, 1990; pp. 111-140.

18. Fengel, D. Aging and fossilization of wood and its components. Wood Sci. Technol. 1991, 25, $153-177$. [CrossRef]

19. Hofstetter, K.; Hinterstoisser, B.; Salmén, L. Moisture uptake in native cellulose-The roles of different hydrogen bonds: A dynamic FT-IR study using deuterium exchange. Cellulose 2006, 13, 131-145. [CrossRef]

20. Hill, C.A.S.; Norton, A.J.; Newman, G. The water vapour sorption properties of Sitka spruce determined using a dynamic vapour sorption apparatus. Wood Sci. Technol. 2010, 44, 497-514. [CrossRef]

21. Engelund, E.T.; Thygesen, L.G.; Svensson, S.; Hill, C.A. A critical discussion of the physics of wood-water interactions. Wood Sci. Technol. 2013, 47, 141-161. [CrossRef]

22. Bjurhager, I.; Ljungdahl, J.; Wallström, L.; Gamstedt, E.K.; Berglund, L.A. Towards improved understanding of PEG-impregnated waterlogged archaeological wood: A model study on recent oak. Holzforschung 2010, 64, 243-250. [CrossRef]

23. Popescu, C.M.; Hill, A.S.C. The water vapour adsorption desorption behaviour of naturally aged Tilia cordata Mill wood. Polym. Degrad. Stab. 2013, 98, 1804-1813. [CrossRef]

24. Sonderegger, W.; Kránitz, K.; Bues, C.T.; Niemz, P. Aging effects on physical and mechanical properties of spruce, fir and oak wood. J. Cult. Herit. 2015, 16, 883-889. [CrossRef]

25. Kranitz, K.; Sonderegger, W.; Bues, C.-T.; Niemz, P. Effects of aging on wood: A literature review. Wood Sci. Technol. 2016, 50, 7-22. [CrossRef]

26. Hosseinpourpia, R.; Echart, A.S.; Adamopoulos, S.; Gabilondo, N.; Eceiza, A. Modification of pea starch and dextrin polymers with isocyanate functional groups. Polymers 2018, 10, 939. [CrossRef] [PubMed]

27. Hosseinpourpia, R.; Adamopoulos, S.; Parsland, C. Utilization of different tall oils for improving the water resistance of cellulosic fibers. J. Appl. Polym. Sci. 2019, 136, 47303. [CrossRef]

28. Hosseinpourpia, R.; Adamopoulos, S.; Mai, C. Effects of acid pre-treatments on the swelling and vapor sorption of thermally modified Scots pine (Pinus sylvestris L.) wood. BioResources 2018, 13, 331-345. [CrossRef]

29. Bodîrlău, R.; Teacă, C.A. Fourier transform infrared spectroscopy and thermal analysis of lignocellulose fillers treated with organic anhydrides. Rom. J. Phys. 2009, 54, 93-104.

30. Cheng, S.; Huang, A.; Wang, S.; Zhang, Q. Effect of different heat treatment temperatures on the chemical composition and structure of Chinese fir wood. BioResources 2016, 11, 4006-4016. [CrossRef]

31. Chai, X.S.; Hou, Q.X.; Zhu, J.Y. Carboxyl groups in wood fibers. 2. The fate of carboxyl groups during alkaline delignification and its application for fiber yield prediction in alkaline pulping. Ind. Eng. Chem. Res. 2003, 42, 5445-5449. [CrossRef]

32. Nzokou, P.; Kamdem, D.P. X-ray photoelectron spectroscopy study of red oak- (Quercus rubra), black cherry(Prunus serotina) and red pine- (Pinus resinosa) extracted wood surfaces. Surf. Interface Anal. 2005, 37, 689-694. [CrossRef]

33. Fors, Y. Sulfur-Related Conservation Concerns for Marine Archaeological Wood The Origin, Speciation and Distribution of Accumulated Sulfur withSome Remedies for the Vasa. Ph.D. Thesis, Stockholm University, Stockholm, Sweden, 2008.

34. Kirk, T.K.; Farrell, R.L. Enzymatic "combustion": The microbial degradation of lignin. Microbiology 1987, 41, 465-505. [CrossRef]

35. Lundell, T.K.; Mäkelä, M.R.; de Vries, R.P.; Hildén, K.S. Genomics, lifestyles and future prospects of wood-decay and litter-decomposing basidiomycota. In Advances in Botanical Research, 1st ed.; Martin, F., Ed.; Academic Press: New York, NY, USA, 2014. [CrossRef]

36. Hammel, K.E.; Cullen, D. Role of fungal peroxidases in biological ligninolysis. Curr. Opin. Plant Biol. 2008, 11, 349-355. [CrossRef]

37. Kim, Y.S.; Singh, A.P. Wood as cultural heritage material and its deterioration by biotic and abiotic agents. In Secondary Xylem Biology Origins, Functions, and Applications; Kim, I.S., Funada, R., Singh, A.P., Eds.; Academic Press: New York, NY, USA, 2016; pp. 233-257. 
38. Tolvaj, L.; Varga, D. Photodegradation of timber of three hardwood species caused by different light sources. Acta Silv. Lignaria Hung. 2012, 8, 145-155. [CrossRef]

39. Tolvaj, L.; Mitsui, K. Light source dependence of the photodegradation of wood. J. Wood Sci. 2005, 51, 468-473. [CrossRef]

40. Lionetto, F.; Sole, R.D.; Cannoletta, D.; Vasapollo, G.; Maffezzoli, A. Monitoring wood degradation during weathering by cellulose crystallinity. Materials 2012, 5, 1910-1922. [CrossRef]

41. Bryne, L.E.; Lausmaa, J.; Ernstsson, M.; Englund, F.; Wålinder, M.E.P. Ageing of modified wood. Part 2: Determination of surface composition of acetylated, furfurylated, and thermally modified wood by XPS and ToF-SIMS. Holzforschung 2010, 64, 305-313. [CrossRef]

42. Chirkova, J.; Irbe, I.; Andersons, B.; Andersone, I. Study of the structure of biodegraded wood using the water vapour sorption method. Int. Biodeterior. Biodegrad. 2006, 58, 162-167. [CrossRef]

43. Esteban, L.G.; de Palacios, P.; Fernandez, F.G.; Guindeo, A.; Conde, M.; Baonza, V. Sorption and hermodynamic properties of juvenile Pinus sylvestris L. wood after 103 years of submersion. Holzforschung 2008, 62, 745-751. [CrossRef]

44. Hosseinpourpia, R.; Adamopoulos, S.; Mai, C. Dynamic vapour sorption of wood and holocellulose modified with thermosetting resins. Wood Sci. Technol. 2016, 50, 165-178. [CrossRef]

45. García-Iruela, A.; Esteban, L.G.; Fernández, F.G.; Palacios, P.; Rodriguez-Navarro, A.B.; Sánchez, L.G.; Hosseinpourpia, R. Effect of degradation on wood hygroscopicity: The case of a 400-year-old coffin. Forests 2020, 11, 712. [CrossRef]

46. Lu, Y.; Pignatello, J.J. Demonstration of the 'conditioning effect' in soil organic matter in support of a pore deformation mechanism for sorption hysteresis. Environ. Sci. Technol. 2002, 36, 4553-4561. [CrossRef]

47. Ghauhan, S.S.; Nagaveni, H.C. Moisture adsorption behaviour of decayed rubber wood. J. Inst. Wood Sci. 2009, 19, 1-6.

48. Esteban, L.G.; Fernandez, F.G.; Garcia, F.; Casasus, A.G.; Palacios, P.P.; Gril, J. Comparison of the hygroscopic behavior of 205-year-old and recently cut juvenile wood from Pinus sylvestris L. Ann. Forest Sci. 2006, 63, 309-317. [CrossRef]

49. Pettersen, R.C. The Chemistry of Solid Wood; Advances in Chemistry Series 20; US Department of Agriculture: Washington, DC, USA, 1984.

50. EN 350. Durability of Wood and Wood-based Products-Testing and Classification of the Durability to Biological Agents of Wood and Wood-Based Materials; European Committee for Standardization: Brussels, Belgium, 2016.

Publisher's Note: MDPI stays neutral with regard to jurisdictional claims in published maps and institutional affiliations.

(C) 2020 by the authors. Licensee MDPI, Basel, Switzerland. This article is an open access article distributed under the terms and conditions of the Creative Commons Attribution (CC BY) license (http://creativecommons.org/licenses/by/4.0/). 